\title{
Implementation of User Centered Design Method in E- Commerce Book Sales Application
}

\author{
R Rahmadani ${ }^{1}$, Mendoza, M. D. ${ }^{2}$, RD Sari $^{3}$, and TTA Putri ${ }^{4}$ \\ \{renirahmadani@unimed.ac.id ${ }^{1}$, aenaen@unimed.ac.id²,ressy@unimed.ac.id ${ }^{3}$, \\ tansatrisna@unimed.ac.id $\left.{ }^{4}\right\}$ \\ PTIK - Universitas Negeri Medan, Indonesia ${ }^{1,2,3,4}$
}

\begin{abstract}
Placement of the end user as a center in the system development process is a philosophy of UCD (User Centered Design). UCD method can help end users to overcome the difficulty of reading and translating the documents that exist in every development. The UCD approach has been supported by a variety of techniques, tools, methods, procedures and processes to help design interactive systems to be more user-centered. In the UCD method the user is at the highest level on all graphical interfaces that are used in conjunction with the entire admin content of the information. The user interaction with the information admin must have the same comfort as his experience using other systems. This writing aims to design an e-commerce application with the UCD method of selling books and providing information relating to books. The methods used for collecting data are interviews and observation of end users, and literature studies. The expected outcome of this design is to be able to provide better services, especially in providing books desired by the buyer.
\end{abstract}

Keywords: Book Sales, User Centered Design, E-Commerce.

\section{Introduction}

Human needs for information is currently increasing, this is in line with the rapid development of technology both in the development of software and hardware. The internet is a form of technological development that can be used to access news, observe business developments, sell and buy transactions, interact with other people through social networks, chat or just browse. Sellers and buyers of goods and services do not have to be in the same place to do the buying and selling process. Internet tools can be used to connect sellers and buyers with a system called e-commerce.

Amazon.com won the Reader's Choice Award in the best e-Commerce web design category in 2009. However, many e-commerce sites do not have a design structure like Amazon.com. Most of the e-commerce sites today have lost their main goal as e-commerce websites and have decreased the usability rate. Many users who are ordinary people who have difficulty understanding and using their site. It needs to be observed before building a web site so that the site design can be based on the user (user-centered-design) and in accordance with the original purpose of why the site was built.

E-Commerce (Electronic Commerce) is a current popular topic that has a major impact on economic and retail services. Many initiatives have arisen in a short time due to e-commerce, such as smart card innovations that facilitate e-commerce, remote payments, and electronic 
checking[1]. The capacity of the internet to access, organize and communicate information in a more efficient way brings a new formula to the relationship between users and entrepreneurs. It also raises new economic and business agents. E-commerce development offers good opportunities for producers and retailers, but this also poses challenges for organizations, with demands for knowing sales strategies and knowledge of buyers in more depth [2].

By using information technology, e-Commerce can be used as a solution to assist producers in the face of competition. The high sales competition that emerged requires that producers can provide a good response. The use of e-commerce can increase the cost efficiency and productivity of producers, so as to increase the ability of producers to compete.

\section{E-Commerce}

E-commerce is an innovation process whose approach looks at the difference between fixed and virtual stores. The benefits of e-commerce can be seen from how activities and taks are carried out at each store, and how to transfer ownership, costs, and efficiency. The evaluation process carried out shows the benefits of using the internet in increasing business efficiency ac[3].

According to the Information System Success Model DeLone \& McLean there are 6 dimensions of success that can be applied in an e-commerce environment[4]:

1) System quality, used to measure e-commerce characteristics are adaptability, availability, usability, reliability, and response time. This is an example of the quality desired by ecommerce system users.

2) Information quality related to content in e-commerce. Content on the web must be as desired, complete, elevant, easy to understand, and safe for buyers and sellers who will carry out transactions through the internet on an ongoing basis.

3) Service quality, all support provided by service providers is applied whenever the service is provided by an information systems department or organizational unit or even an internet service provider. This dimension is the most important dimension in e-commerce because now users are customers and not employees. Therefore poor service will cause loss of customers and sales.

4) Usage measures everything from website visits, instructions on the web, information returns and transaction execution.

5) User satisfaction is the most important thing in measuring customer opinion on ecommerce systems and must cover the entire customer experience from information gathering through transactions, payments, receipts, and services.

6) Net benefits are used to measure the degree of success, because it captures the balance of positive and negative impacts of e-commerce on customers, providers, employees, marketing organizations, industry, economy, and society as a whole.

\section{UCD (User Centered Design)}

User-centered design can be categorized as a problem-solving stage that requires designers to analyze and predict how users use interfaces and test the validity of their opinions regarding user habits in the use of interfaces in real life. In designing a web or a system, UCD must provide the best service for users and online shop owners[5]. The quality of the user interface and the quality of information provided by e-commerce services have a direct impact on increasing customer satisfaction and loyalty in the e-commerce market[6]. Therefore it is very important to know the user before starting the design[5].

Usability is a term that has a different definition in every field. In the field of industrial engineering, product research and development, computer systems, and science library usability 
are associated with lessons about interaction between humans and machines and commitment to users. Dumas and Reddish said that Usability means that people who use products can complete their tasks quickly and easily[7].

User-centered design incorporates the principle of usability into product design and places a focus on the user during project development. According to Gould and Lewis, there are three UCD principles: an initial focus on tasks and users, empirical measures on product use, and interactive design to get user input on design and modification[7][8].

Software development using UCD, users are involved at all stages. This includes analysis, design, development stage, ordering process, customer support and advertising. Instead of being technology driven, user centered design is user driven. User requirements and user interface design are not only accidental or additional aspects that occur during the process, but must be a driver of technical processes[9][10].

During the analysis phase, UCD uses many interview techniques to know the user. In the context of knowing the work of user, techniques that are often used in individuals is a face-toface setting. This technique observes the user as long as they complete tasks on work that involve 'thinking aloud' or 'talk right after.' Another interview investigates user information related to the task and involves several types of card sorting. Human Computer Interaction researchers conclude that traditional sales techniques that focus on groups and are less useful because the techniques are carried out in the context of the actual task[10].

\section{Analysis, Results and Discussion}

In general, the method is a comprehensive plan of a series of activity processes that are in accordance with the program designed. The following are the aspects that need to be considered for a successful system.

a) Online Book Shops Script

Table 1. Sricpt for Admin

\begin{tabular}{|c|c|c|}
\hline Sricpt Name & Component & Specific Action \\
\hline \multirow[t]{4}{*}{$\begin{array}{l}\text { Website } \\
\text { Maintenance }\end{array}$} & Login & $\begin{array}{ll}\text { - } & \text { Input username and password } \\
\text { - } & \text { Log in administrator web page. }\end{array}$ \\
\hline & $\begin{array}{l}\text { Manage books } \\
\text { reservations }\end{array}$ & $\begin{array}{l}\text { - } \quad \text { Checking book avaibility } \\
\text { - } \quad \text { Checking payment confirmation/ Book } \\
\text { order } \\
\text { 1. Approving / rejecting payment } \\
\text { confirmation or books reservation. }\end{array}$ \\
\hline & News update & $\begin{array}{ll}- & \text { Fill in news date } \\
- & \text { Fill in news title } \\
- & \text { Fill in news detail } \\
& \text { 2. News Saving }\end{array}$ \\
\hline & Books updating & $\begin{array}{ll}- & \text { Get in to Books Menu } \\
\text { - } & \text { Fill in book's name } \\
\text { - } & \text { Fill in book's description } \\
\text { 3. Books Categorize }\end{array}$ \\
\hline
\end{tabular}




\begin{tabular}{|c|c|c|}
\hline Sricpt Name & Component & Specific Action \\
\hline $\begin{array}{l}\text { Website } \\
\text { Maintenance }\end{array}$ & Login & $\begin{array}{ll}- & \text { Input username and password } \\
\text { - } & \text { Log in administrator web page. }\end{array}$ \\
\hline \multirow[t]{2}{*}{$\begin{array}{l}\text { Respond to } \\
\text { Member Forum }\end{array}$} & Login & $\begin{array}{l}\text { - Fill in username and password } \\
\text { Get in to forum page }\end{array}$ \\
\hline & Search new message & $\begin{array}{l}\text { - } \quad \text { Get in to forum page } \\
\text { - } \quad \text { Enter the search period } \\
\text { - } \quad \text { Select the latest messages that are displayed } \\
\text { 4. Respond to Messages } \\
\text { 5. Message storage }\end{array}$ \\
\hline
\end{tabular}

Table 2. Sricpt for Customers

\begin{tabular}{|c|c|c|}
\hline Sricpt Name & Component & Specific Action \\
\hline \multirow[t]{4}{*}{$\begin{array}{l}\text { Access exhibition } \\
\text { information }\end{array}$} & Reading News & $\begin{array}{ll}\text { - } & \text { Look into the news column } \\
\text { - } & \text { Choose the news title } \\
\text { - } & \text { Read news details }\end{array}$ \\
\hline & Looking for books data & $\begin{array}{ll}- & \text { Enter the book search menu } \\
- & \text { Choose item categories } \\
- & \text { Enter the book key you are looking for } \\
- & \text { See book listings of search results }\end{array}$ \\
\hline & Ordering books & $\begin{array}{ll}- & \text { Enter the book search menu } \\
- & \text { Choose a book category } \\
\text { - } & \text { Enter the book key you are looking for } \\
\text { - } & \text { Fill in the order data (name, telephone number, } \\
\text { shipping address) } \\
\text { - } & \text { Sending order data } \\
\text { - } & \text { Waiting for payment confirmation max } 2 \times 24 \\
\text { hours }\end{array}$ \\
\hline & Filling Guest Book & $\begin{array}{ll}- & \text { Enter the guest book column } \\
- & \text { Fill in visitor data (name, email) } \\
- & \text { Fill out messages / questions / } \\
\text { - } & \text { suggestions } \\
\text { Save message }\end{array}$ \\
\hline
\end{tabular}


b) Custominzing

a. The facility to customize the website is given to the user and admin with consideration of the needs and interests of each party.

b. Customization facilities for users: language selection (Indonesian and English)

c. Customization facilities for administrators aim to make administrators easily maintain and adjust the appearance and content of the website as needed

c) Customization facilities provided to website administrators

a. Customizing web site content

b. Customizing banner and header images

c. Polling customization

d. SMS Customization

e. Customizing guest book

f. Add, delete, edit menu

g. Selection of menu classification, which consists of: main content, potential and links.

h. Add, delete edit sub menu

i. Ordering menu display

j. Fill in the news details on each menu

\section{Conclusion}

In this paper we have examine that e-commerce is a sales system that is dynamic, webbased, and can be integrated with social media to increase promotion. The company needs to design its e-commerce page using user centered design to maintain closeness between customers and companies and make these customers comfortable by knowing customer desires, making promos, and bonuses, so the company has gained intangible benefits. This advantage is seen from the increase in customers and customer loyalty.

\section{References}

[1] A. Gunasekaran., H.B. Marri., R.E. McGaughey., \& M.D. Nebhwani. E-commerce and Its Impact on Operations Management, International Journal of Production Economics, 75, 185-197. https://doi.org/10.1016/S0925-5273(01)00191-8. (2002)

[2] Crespo, A. H. \& Rodriguez del Bosque, I. The Influence of the Commercial Features of the Internet on the Adoption of E-Commerce by Consumers, Electronic Commerce Research and Applications, 9, 562-575. https://doi:10.1016/j.elerap.2010.04.006. (2010)

[3] Burt, S. \& Sparks, L E-commerce and the retail process: a review, Journal of Retailing and Consumer Services, 10, 275-286. https://doi.org/10.1016/S0969-6989(02)00062-0. (2003)

[4] DeLone, W. H. \& McLean, E. R. Measuring e-Commerce Success: Applying the DeLone \& McLean Information Systems Success Model, International Journal of Electronic Commerce, 9(1), 31-47. http://dx.doi.org/10.1080/10864415.2004.11044317. (2004)

[5] Wang, R. \& Wang, X. User-Centered Design and Visualization of Service Oriented Recommender Agents: An Approach to Achieve Better Consumers' Involvement in ECommerce Systems, IEEE International Conference on e-Business Engineering, 545550. 10.1109/ICEBE.2009.87. (2009) 
[6] Eid, M. I. Determinants of E-Commerce Customer Satisfaction, Trust, and Loyalty In Saudi Arabia, Journal of Electronic Commerce Research, 12(1), 78-93. (2011)

[7] Manzari, L.\& Trinidad-Christensen, J. User-Centered Design of A Web Site for Library and Information Science Students: Heuristic Evaluation and Usability Testing. Information Technology and Libraries, 25(3), 163-169. (2006)

[8] Gould, J. D., \& Lewis, C. Designing for Usability: Key Principles and What Designers Think. Communications of the ACM, 28(3), 300-311. (1985)

[9] Mayhew, D., The Usability Engineering Lifecycle: A Practitioner's Handbook for User Interface Design. Morgan Kaufmann, San Francisco. (1999)

[10] Chan, S. S., Wolfe, R. J., \& Fang, X. Issues and strategies for integrating HCI in masters level MIS and e-commerce programs. International Journal of Human-Computer Studies, 59(4), 497-520. (2003) 